\title{
THE LEARNING PROCESS OF PHYSICAL AND HEALTH EDUCATION SUBJECT IN CLASS VIII OF SMP N 4 KOTA PAYAKUMBUH
}

\author{
Kamal Firdaus \\ State University of Padang, Komp. Parupuk Raya B 36 Tabing Padang, West Sumatera 25171 \\ dr.kamalfirdaus.mkes.aifo@gmail.com
}

\begin{abstract}
The problem of this research was initiated by the learning process of Physical, Sport and Health Education which was not run well. This research was aimed at revealing the students' intrinsic and extrinsic motivation toward the learning process of Physical, Sport and Health Education subject at SMP N 1 Kota Payakumbuh.

This was a descriptive research. The population of the research was all of students (287) in grade VIII of SMP N 4 Kota Payakumbuh. By using random sampling technique, 20\% (55 students) of the population were taken as the sample. The data were obtained by making use of the questionnaire of Gudman's scale. The data gathered then were analyzed by using statistic of descriptive percentage.

Based on the results of data analysis, it was figured out that: 1) the students' intrinsic motivation toward Physical, Sport and Health Education subject at SMP N 4 Kota Payakumbuh is $44.6 \%$ (average), and 2) the students' extrinsic motivation toward Physical, Sport and Health Education subject is $41.8 \%$ (average). From these results, it is concluded that the students' motivation toward Physical, Sport and Health Education subject, in general, is in average category.
\end{abstract}

\section{A. INTRODUCTION}

\section{Background of the Problems}

Education is one of the spheres that plays an important role in establishing Indonesian people either physically or mentally. It is intended to develop human resources systematically, thoroughly and optimally on the basis of Pancasila as early as possible. This goal is in accordance with the System of National Education in Chapter II Article 3 of the Law of Republic Indonesia No. 20 Year 2003 confirming that the national education is functioned to develop capability and to form prestigious characteristics and culture of the nation. It also aims to develop the students' potential to be the ones who are faithful and pious to the Almighty God, noble, healthy, knowledgeable, skilled, creative, independent, and become democratic responsible citizens.

Based on the above explanation, it is concluded that education is an effort done by the government to develop the students' potential so that they could be skillful, knowledgeable, creative, healthy, and independent. Furthermore, education could establish the characteristics and the identity of the students to be better, more prestigious and devoted to the Almighty God, and be responsible to themselves, their families, others and the nation.

One of the efforts done to achieve the goals of the national education is through education in Junior High School for three years. One of the subjects taught to the Junior High School student is Physical, Sport and Health Education. The learning process of this subject in Elementary and High School levels of Curriculum 2006 is focused on the development of physical fitness and movement skills aspects.

The two aspects mentioned above are regarded as the main components in the learning process of Physical, Sport and Health subject. The two encourage the students to be more enthusiastic in performing sport activities at school. The Department of National Education (2010:10) states that the Physical, Sport and Health Education is meant to develop physical fitness, movement skills, critical thinking skills, social skills, logical thinking skills, emotional stability, moral acts, healthy life habits, and to introduce clean environment through physical, sport and health activities chosen and planned systematically in order to achieve the goals of National Education.

The above notions divulge the importance of physical, sport and health education for the students especially to develop their potential and a wide range of favorite sport skills, to maintain their physical fitness, and to raise healthy life habits, and sportsmanship and cooperative values. In addition, it is also to increase movement activities and physical growth.

Furthermore, physical education is also intended to give chance to the students to learn various activities to establish and develop their potentials, such as physique, mental, social, emotional and moral aspects. To achieve the goals, the role of the teachers is highly crucial. They are the main components responsible for the teaching and learning process. To make the process run as it is planned, the teachers are required to 
maximally develop the instructional strategies and improve their skill in motivating the students to get interested in the learning process of Physical, Sport and Health Education subject.

Based on the result of the preliminary observation done at SMP Negeri 4 Kota Payakumbuh, it is revealed that the students were less discipline, unserious, less enthusiastic, and remained sitting on the chairs during the learning process. The students' reluctance to perform physical, sport and health education activities at SMP N 4 Kota Payakumbuh was likely to be caused by the students' lack of motivation either intrinsic or extrinsic. The other factors affecting the students' unwillingness to do physical activities were the instructional media and method used, instructional modification, facilities and infrastructures, attention and supervision from the principal toward physical, sport and health education learning process, instructional strategies, knowledge and skill of the teachers, and learning atmosphere. The factors were interrelated one to another.

Of the factors mentioned, the learning process which seemed to be unable to encourage the students to get involved in is considered as the main cause of the problem. The instructional strategies applied did not work to attract the students' attention and motivate them to learn enthusiastically. Motivation is highly important in encouraging someone to achieve their ambition. It helps students to grow up the motives within themselves to act passionately.

In order to obtain data and information about the students' motivation in the learning process of Physical, Sport and Health Education subject at SMP N 4 Kota Payakumbuh, this research was conducted.

\section{The Objectives of the Research}

This research was intended to reveal:

1. The students' intrinsic motivation in the learning process of Physical, Sport and Health Education subject at SMP N 4 Kota Payakumbuh.

2. The students' intrinsic motivation in the learning process of Physical, Sport and Health Education subject at SMP N 4 Kota Payakumbuh.

\section{Theoretical Framework}

\section{a. The Definition of Motivation}

Motivation is derived from Latin language "mavere" meaning activating or encouraging someone to move. Furthermore, motivation is also drawn from the word "motive" meaning the power or energy encouraging someone to do something. Motive can be defined as the power coming from either in or out of a subject to perform particular activities in order to achieve a goal. In addition, motive can also be defined as an internal condition which acts as an activator.

b. Types of Motivation

According to Hamalik (2001:162), motivation comprises of intrinsic motivation and extrinsic motivation.

1. Intrinsic Motivation

Setyobroto (2002:24) says that intrinsic motivation is motivation that rises within oneself. For example, the students would take part in an activity when they think that it is advantageous and they would join it based on their own willingness.

According to Asrori (2007:183), intrinsic motivation is motivation which comes up from oneself to commit an act in order to achieve maximum outcomes. In the other side, Sardiman (2012:89) states that intrinsic motivation is the motives that are active and functioned without any stimulus from outside. For example, the students study or accomplish their tasks because they want to acquire knowledge, get score or skill, and change their behavior constructively, but not for other purposes.

\section{Extrinsic Motivation}

According to Setyobroto (2002:24), extrinsic motivation is that triggered by other factors beyond learning situation such as semester credit, certificate, rewards, and negative competition.

Asrori (2007:183) mentions that extrinsic motivation is motivation coming from outside which is in the form of encouragement from others. Furthermore, Hamalik (2001:163) proposes that extrinsic motivation is encouragement coming from outside triggering individual to participate in an activity. For example, a student is willing to learn because tomorrow he will take an exam, and he expects to get a score so that he will get a compliment from others. 
Hence, extrinsic motivation is not based on the condition within the students themselves, instead it rises as there is a stimulus from external factors so that the goals to be achieved are out of the process. The extrinsic motivation would encourage students to achieve the objectives determined. The further the goals to be achieved, the stronger the motivation raises.

In order to grow the students' motivation effectively, the teachers have to learn their needs so that the instructional strategies applied are matched to.

Based on the views proposed by several experts mentioned previously, it is identified that they have similar notion on motivation. Therefore, it is concluded that the indicators of extrinsic motivation are compliment, learning progress report, reward, punishment, recognition and competition.

\section{Conceptual Framework}

On the basis of the theoretical review deciphered above, it could be said that the learning outcomes of the female students were affected by both intrinsic and extrinsic motivation. The female students having good learning motivation tended to take parts in the learning process well. Contrarily, those having less motivation would be lazy to get involved in the process and tended to get poor achievement. To show the variables researched and the correlation among the variables, the following conceptual framework was drawn.

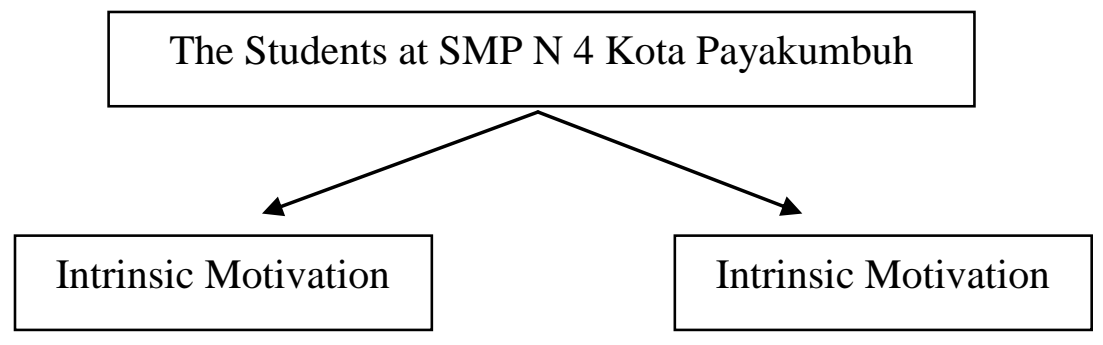

Picture 1: Conceptual Framework of the Research

\section{B. RESEARCH METHOD}

This was descriptive research which was intended to reveal a condition as it was. According to Abdurrahman, et al (2011:18), descriptive research is a research conducted to get a description on a variable or more without comparing or correlating it to others variables. This research was conducted at SMP N 4 Kota Payakumbuh from January to February 2016.

The population of the research was 287 students studying at SMP N 4 Kota Payakumbuh from class VIII ${ }^{1}$ to $\mathrm{VIII}^{9}$. The sample was chosen by using random sampling technique. According to Ridwan (2012:41), random sampling technique is done by randomly taking the sample from a population regardless to their strata (level). Of the population, $20 \%(55 \%)$ students were chosen as the sample.

\section{FINDINGS AND DISCUSSIONS}

\section{Intrinsic Motivation}

The number of the items to be answered by the respondents in intrinsic motivation variable is 13 . The number of the respondents answering No is $396(55.4 \%)$ while that of the respondents answering Yes is $319(44.6 \%)$. The average score was 0.45 , the standard of deviation is 0.497 , the median is 0 , the variance is 0.247 , the minimum score is 0 and the maximum score is 1 . The following histogram describes the frequency of intrinsic motivation variable in the form of percentage. 


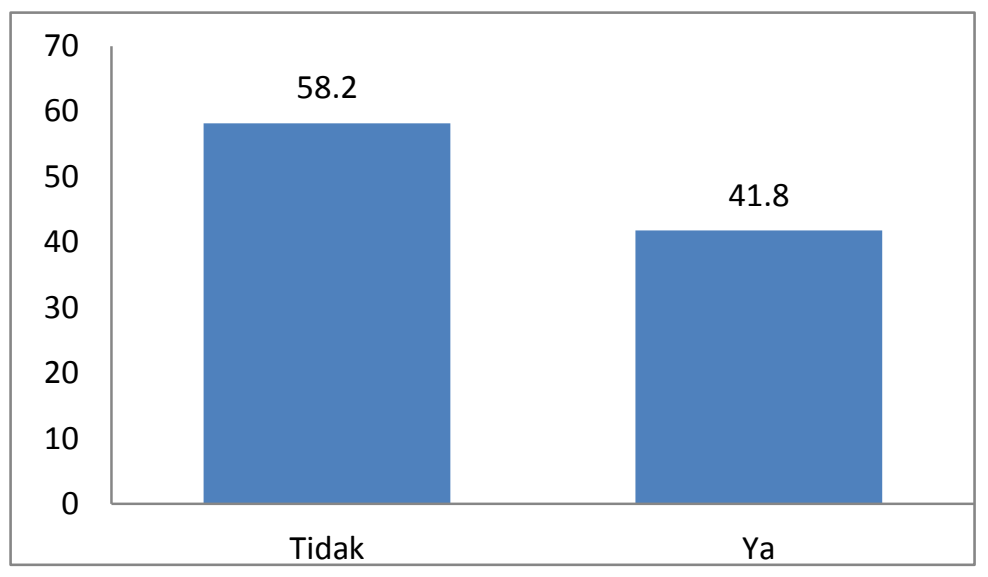

\section{Graphic 1: The Histogram of the Frequency Distribution of Intrinsic Motivation Variable}

\section{Extrinsic Motivation}

There were 14 items contained in extrinsic motivation variable. The respondents would give their answers based on their own opinion. The result of the tabulation shows that $448(58.2 \%)$ respondents answered No while $322(41.8 \%)$ of whom answered Yes. The average score is 0.42 , the standard of deviation is 0.494 , the median is 0 , the variance is 0.244 , the minimum score is 0 and the maximum score is 1 . The following is the histogram describing the frequency of extrinsic motivation variable in the form of percentage:

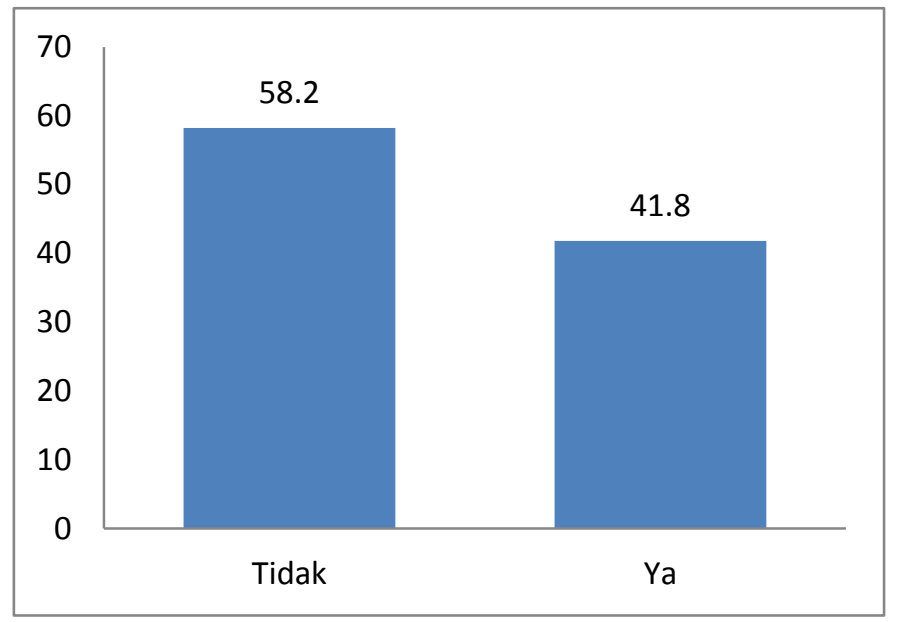

Graphic 2: The Histogram of the Frequency Distribution of Extrinsic Motivation Variable

\section{CONCLUSIONS AND SUGGESTIONS}

\section{a. Conclusions}

Based on the results of the research on the learning process of Physical, Sport and Health Education subject at SMP N 4 Kota Payakumbuh, the following conclusions were drawn:

1. The students' intrinsic motivation toward Physical, Sport and Health Education subject is $44.6 \%$ (average).

2. The students' extrinsic motivation toward Physical, Sport and Health Education subject is $41.8 \%$ (average).

\section{b. Suggestions}

Based on the research findings, it is suggested to:

1. The teachers of physical, sport and health education subject especially those teaching at SMP N 4 Kota Payakumbuh to increase the students' motivation by presenting interesting learning materials, giving compliments, rewards, appreciation and report on learning progress. 
2. To the relevant parties such as the Department of Education and the headmaster to provide facilities and infrastructures needed in the learning process of Physical, Sport and Health Education subject. This is intended to make the students more enthusiastic to learn.

3. The students at SMP N 4 Kota Payakumbuh to increase their motivation toward Physical, Sport and Health Education subject so that the goals of the instruction could be achieved.

4. To the parents to encourage their children to take parts in the learning process of Physical, Sport and Health Education subject.

5. To the upcoming researchers to conduct deeper researches on the learning process of Physical, Sport and Health Education subject from different factors.

\section{References}

1. Abdurrahman, Maman, et al. 2011. Manajemen Penelitian. CV Pustaka Setia

2. Asrori, Mohammad. 2007. Psikologi Pembelajaran. Bandung: CV Wacana Prima

3. Depdiknas. 2010. Tes Kesegaran Jasmani Indonesia. Jakarta: Pusat Pengembangan Kualitas Jasmani

4. Hamalik Oemar. 2001. Proses Belajar Mengajar. Jakarta: Bumi Aksara

5. Sardiman, A.M. 2012. Belajar Mengajar Interaksi dan Motivasi. Jakarta: PT. Raja Grafindo Persada

6. Setyobroto. 2002. Psikologi Olahraga. Jakarta: Percetakan Universitas Negeri Padang

\section{Author' biography}

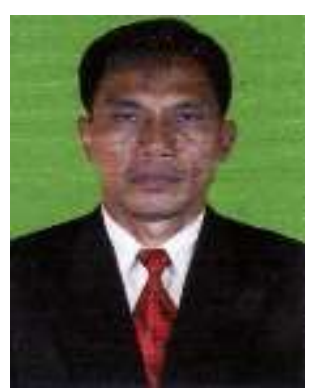

Firdaus Kamal, born in Jambi 12 Novembers 1962, was the second of Mr. H. Sutan Pameran (Alm)and Mrs. Hj. Elzas M. (from Bukittinggi).

Married to Agus nelly and happing a child nam ed Rahmat Al Azj z katialy, Student of PembangunanUNP Senior High School.

Education finish his Prim ary School in SD Negeri 01 Bajubang Jam bi in 1975, High School in Bajubang Jam bi in 1978, Senior Figh School in Bajubang Jam bi in 1981, and Sport Science Faclity, Institute a Science Theacher and Science Education of Padang in 1985, in 1997 continued Megister Program Sport Science in Airlangga Univercity and finisehed 1999, in 2009 continued Doctor

Program Sport Education Studies in Sem arang Univercity and finished 2012.

In 1987 appointed School Theacher Gym Teacher and in 1990 m ove d to the transition to Ins titute a Science Theacher and Science Education of Padang until now.Scientific Activities, Sport Science Thecnology (Scientific Papers, 1998), PB Pelti Ins tructur (Workshop, 1994), The Role of Secology, Psychology and Sports Bisiness in Supporting the Improvem en of Sports Performence (Sympos ium, 1997), Internas ional Tenis Federation Coaching Works hop (2000), Inters ection Scientific Work of Science and Thecnology of Sports (Workshop, 2007).

Scientific Work (Book), General Science of Sport (UPI Bandung, 2003), Sports Marketing (UPI Bandung, 2006), Sport Managem ent (UPI Bandung, 2008). 